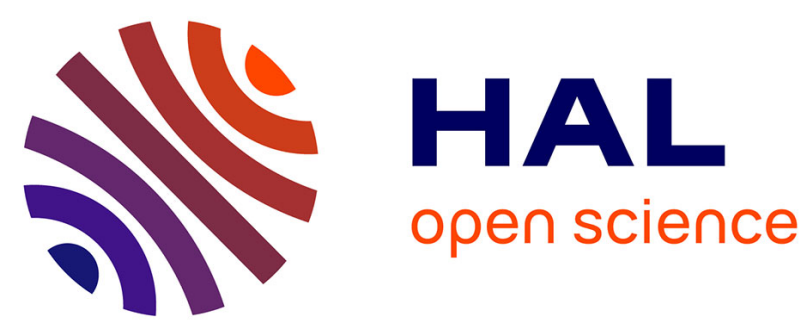

\title{
Fluorine migration in a soil bed submitted to an electric field : influence of electric potential on fluorine removal
} Véronique Pomes, Maria Aurora Fernandez, Nathalie Costarramone, Bruno Grano, Didier Houi

\section{- To cite this version:}

Véronique Pomes, Maria Aurora Fernandez, Nathalie Costarramone, Bruno Grano, Didier Houi. Fluorine migration in a soil bed submitted to an electric field: influence of electric potential on fluorine removal. Colloids and Surfaces A: Physicochemical and Engineering Aspects, 1999, 159 (n²-3), p. 481-490. 10.1016/S0927-7757(99)00285-X . hal-01846945

\section{HAL Id: hal-01846945 \\ https://hal.science/hal-01846945}

Submitted on 7 Nov 2019

HAL is a multi-disciplinary open access archive for the deposit and dissemination of scientific research documents, whether they are published or not. The documents may come from teaching and research institutions in France or abroad, or from public or private research centers.
L'archive ouverte pluridisciplinaire HAL, est destinée au dépôt et à la diffusion de documents scientifiques de niveau recherche, publiés ou non, émanant des établissements d'enseignement et de recherche français ou étrangers, des laboratoires publics ou privés. 


\title{
Fluorine migration in a soil bed submitted to an electric field: influence of electric potential on fluorine removal
}

\author{
V. Pomes *, A. Fernandez, N. Costarramone ${ }^{1}$, B. Grano, D. Houi ${ }^{2}$ \\ Centre Energétique et Environnement, Ecole des Mines d'Albi, Route de Teillet, 81013 Albi CT, Cedex 09, France
}

\begin{abstract}
Transport phenomena in soils submitted to an electric field are the basis of a soil decontamination technique called electromigration or more generally electrokinetic remediation. An experimental study was carried out in order to determine the influence of the applied electric potential on the most important variables for the treatment: the amount of pollutant removed and the current intensity produced. Physicochemical and transport aspects of the process are taken into account in order to prove the feasibility and the efficiency of the technique to treat a fluorine contaminated soil.
\end{abstract}

Keywords: Soil bed; Electric field; Electromigration; Electrokinetic remediation

\section{Introduction}

Contaminated soils are a threat to the environment so, a treatment or a confinement of these sites seem to be necessary. Contaminated industrial sites close to cities represent important economic opportunities for development and, in these cases, confinement is not an available solution. Treatment processes usually employed (bioremediation, venting, excavating/incineration) [15] are sometimes ineffective especially in the case of soils which have a very low hydraulic perme-

\footnotetext{
* Corresponding author.

${ }^{1}$ Present address: Laboratoire de Chimie Analytique, Université de Pau et des Pays de l'Adour

${ }^{2}$ Present address: Institut de Mécanique des Fluides de Toulouse
}

ability or which are contaminated by heavy metals.

Electrokinetic remediation is an in-situ process that is being used in the United-States and in the Netherlands [14] for the treatment of soils of very low permeability containing several inorganic (like heavy metals) or organic (like light hydrocarbons) chemical species [2-21].

The implementation of electrokinetic remediation is easy. It consists in inserting two electrodes in the soil and applying an electric field between them. The electric field produces the migration of chemical species towards the electrodes where the pollutant in the liquid phase is removed. This electrokinetic soil processing allows simultaneous the transport and the removal of one or several pollutants. 
Several laboratory, pilot-scale, or in-situ studies have widely demonstrated the efficiency and the feasibility of the electrokinetic remediation technique for the clean-up of contaminated soils $[1,3,4]$. However, physical and chemical phenomena are complex and few phenomenological studies are reported in the literature. The removal of a pollutant by the electrokinetic technique is performed, trying to obtain a maximum amount of contaminant and consuming a minimum of electricity, especially for industrial applications. The amount of pollutant removed and the current intensity produced during the treatment are dependent on the electric field imposed between the electrodes. The cost of soil electro-decontamination is directly proportional to the current produced during the treatment, which is dependent on the applied electric field. The aim of this work was to study the influence of the electric potential on the most important variables of the treatment: the amount of pollutant removed at the electrodes and the current produced. For this, three different electric potentials were applied between the electrodes of three similar electro-decontamination cells. Fluorine was the pollutant studied.

Firstly, transport phenomena during the electromigration are reviewed. Then, the experimental set-up, the analysed variables, the characteristics and the composition of the soil used are presented and finally the results obtained are discussed.

\section{Transport phenomena in a soil}

During the soil treatment some transport and physicochemical phenomena could take place: electrokinetic, diffusion, thermal and hydrodynamic phenomena are coupled between themselves and with chemical reactions [1]. Chemical reactions could appear between species in solution (homogeneous reactions such as complexation) or with the porous medium (heterogeneous reactions such as adsorption or ion exchange). The heterogeneous reactions can induce other transport phenomena such as species diffusion in the boundary layer.

In general, thermal phenomena, transport phenomena and the pollutant reactivity with the medium are the subjects of separate studies even when their coupling is identified.

The following transport phenomena presented are on the one hand electrokinetic phenomena and on the other hand more classical phenomena such as advection and diffusion.

\subsection{Electrokinetic phenomena}

The electric field imposed on a soil induces two type of phenomena: electrolysis reactions at the electrodes and two electrokinetic transport phenomena in the porous medium, electroosmosis and electromigration. The soil is usually assimilated with a porous medium formed by a fixed matrix and then the transport of soil particles, or electrophoresis, is not considered. When the particle size is close to zero, like ions, their migration, or electromigration, is possible. In fact, for particles so small, the retarding effects of their chemical environment disappear [6] and the electromigration could be considered as a particular case of electrophoresis. The electric field produces the migration of the cations towards the cathode and the anions towards the anode.

In order to explain the transport of water molecules through the porous medium, caused by the electric field, or electroosmosis, several theories have been proposed. The Helmoltz-Smoluchowski theory [22] is based on the electric double layer and the zeta potential concepts. The electric field induces the motion of water on the double layer, parallel to the solid wall, as a function of the zeta potential. Then, this motion causes the transport of the pore fluid by momentum transfer. However, the measure of zeta potential is not easy in the case of media of low permeability and even then it is usually done by electrophoresis, for suspended particles, or by a streaming potential in permeable porous media. Nevertheless, the meaning of a such measurement in a porous medium of low permeability, submitted to an electric field, is not today clearly defined. In fact, ions orientate themselves in the medium, so charges can appear or disappear and the zeta potential of the soil can be modified.

From Darmois [7] the electroosmosis phenomenon is attributed to an ion hydration differ- 
ence between anions and cations. Ballou [5] has compared, by several techniques, the ion hydration numbers to the amount of water moved by electroosmosis, in homonionic clay. He establishes that the amount of water moved per ion discharged is very large compared with their hydration numbers. Then, Darmois's theory in clays does not appear satisfactory.

Casagrande [10] has proved that it is possible to determine the electroosmotic water flow in a porous medium, at a macroscopic scale. He has stated a simple law (1), valid for all soils with great precision. Water flow moved by electroosmosis $\left(q_{\mathrm{e}}\right)$ is related to the applied electric potential gradient $(E)$ to the porous medium, the soil section $(S)$, the porosity $(n)$ and a constant called electroosmotic permeability $\left(k_{\mathrm{e}}\right)$

$q_{\mathrm{e}}=k_{\mathrm{e}} S n E$ with $E=V / L$

$V$ represents the electric potential and $L$ is the length of the porous medium.

This law is generally employed for the calculation of electroosmotic flows in soils during an electro-decontamination process. The electroosmotic permeability coefficient has been measured for several soils of different physicochemical natures [9]. This coefficient is commonly considered to be constant for a given soil and equal to $5 \times 10^{-9} \mathrm{~m}^{2} \mathrm{~V}^{-1} \mathrm{~s}^{-1}$ for an electric field applied of $1 \mathrm{~V} \mathrm{~cm}^{-1}$.

Table 1

Characteristic time scales based on a length scale of $0.01 \mathrm{~m}$ [13]

\begin{tabular}{ll}
\hline Transport process & Chemical process \\
\hline $\begin{array}{l}\text { Electromigration, } \\
10^{2} \mathrm{~s}\end{array}$ & Dissociation of strong acid, $10^{-8} \mathrm{~s}$ \\
$\begin{array}{l}\text { Electroosmosis, } \\
10^{4} \mathrm{~s}\end{array}$ & Dissociation of weak acid, $10^{-6} \mathrm{~s}$ \\
Diffusion, $10^{5} \mathrm{~s}$ & Inorganic complexation, $10^{-6}$ to \\
& $10^{-2} \mathrm{~s}$ \\
& Adsorption/ion exchange, $10^{1}$ to \\
& $10^{4} \mathrm{~s}$ \\
& Dissolution/precipitation, $10^{2}$ to \\
& $10^{7} \mathrm{~s}$ \\
\hline
\end{tabular}

\subsection{The transport phenomena}

In addition to electrokinetic transport, other more classical phenomena such as advection and diffusion must be considered.

Casagrande's law (1) for electroosmosis was derived from Darcy's law (2) for hydrodynamic convection [12]. Both employ the concept of permeability.

$q_{\mathrm{h}}=\frac{k_{\mathrm{h}} S n H}{L}$

$q_{\mathrm{h}}$ represents the water flow, $k_{\mathrm{h}}$ is the hydraulic permeability and $H$ is the hydraulic head.

The main difference being that the hydraulic permeability is due to the hydraulic head gradient $H / L$ whereas electroosmotic permeability is due to the electric potential gradient $V / L$. In addition, $k_{\mathrm{h}}$ is a function of the particle size and of the porosity even when $K_{\mathrm{e}}$ is considered as constant for a soil $[9,12]$.

In soils composed of coarse or medium particles, water motion is essentially due to convective transport [9]. Then, the electroosmotic permeability is negligible when compared with hydraulic permeability and so, to decontaminate such soils washing is usually preferred. Electroosmosis becomes the preponderant transport in soils of very low hydraulic permeability, such as clays. This can explain the significant water motions observed in clay soils, usually impermeable, under an electric field.

The concentration gradients in the pore solution induce a diffusive transport of chemical species which is independent of the electric field. The analysis of transport phenomena by characteristic time (Table 1) shows that the species diffusion is usually very slow when compared with electrokinetic transport.

Therefore pollutant recovery by diffusion is often neglected with respect to other transport phenomena. However, diffusion can be a limiting step for heterogeneous reactions, such as ion exchange, and then it can control the recovery of the fraction of pollutant fixed in the soil. Diffusion is often considered as a negligible transport phenomenon, but its limiting effect on the species solubilisation can't be neglected. 


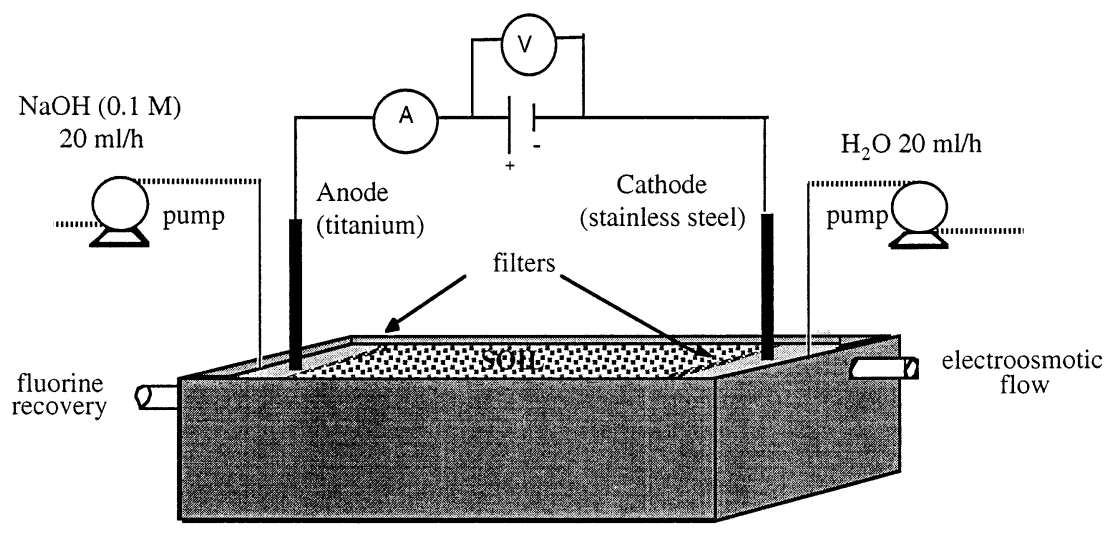

Fig. 1. Electromigration cell.

In order to study the influence of the electric potential on the most important variables for the electrokinetic treatment of a soil, three similar electro-decontamination cells were used. The cells were filled with an industrial soil polluted by fluorine [11]. Three different electric potentials were applied between the electrodes and the variables measured during the experiments were the fluoride concentration at the over-flows of the cells to know the amount of pollutant removed, the current intensity to estimate the electric current consumed, and the $\mathrm{pH}$ of the medium to determine its chemical state. Experiments carried out and results obtained are described below.

\section{Materials and methods}

\subsection{Experimental set-up}

Fig. 1 shows the electroremediation cell used (dimensions are $4 \times 4 \times 50 \mathrm{~cm}^{3}$ ). This cell was made of PVC and closed with a cover in order to avoid water evaporation. At each end of the cell, two compartments contained the $3.5 \mathrm{~cm}$ square electrodes, being the titanium anode and the stainless steel cathode. Two polyamide filters guaranteed the separation between the soil and each electrolytic compartment. These were equipped with overflows and were supplied with reagents by peristaltic pumps which delivered a flow of $20 \mathrm{ml} \mathrm{h}^{-1}$. The anode was supplied with
$\mathrm{NaOH}(0.1 \mathrm{M})$ and the cathode with distilled water. Two multimeters allowed the measurement of the current intensity produced in the circuit and the electric potential between the electrodes which was provided by a constant voltage generator of $0-150 \mathrm{~V}$.

The control of the $\mathrm{pH}$ of the medium and the solubility of the fluorine was allowed by the addition of reagents at the electrodes. Water electrolysis reactions are also dependent on the $\mathrm{pH}$ of the medium:

At the cathode:

$2 \mathrm{H}_{3} \mathrm{O}^{+}+2 \mathrm{e}^{-} \leftrightarrow \mathrm{H}_{2}+2 \mathrm{H}_{2} \mathrm{O} \mathrm{pH}<7$

$\mathrm{E}_{\left(\mathrm{H}_{3} \mathrm{O}^{+} / \mathrm{H}_{2}\right)}^{\mathrm{o}}=0 \mathrm{~V}$ at $\mathrm{pH} 0$

$2 \mathrm{H}_{2} \mathrm{O}+2 \mathrm{e}^{-} \leftrightarrow \mathrm{H}_{2}+2 \mathrm{OH}^{-} \mathrm{pH} \geq 7$

$E_{\left(\mathrm{H}_{2} \mathrm{O} / \mathrm{H}_{2}\right)}^{\circ}=-0.42 \mathrm{~V}$ at $\mathrm{pH} 7$

$E_{\left(\mathrm{H}_{2} \mathrm{O} / \mathrm{H}_{2}\right)}^{\circ}=-0.84 \mathrm{~V}$ at $\mathrm{pH} 14$

At the anode:

$3 \mathrm{H}_{2} \mathrm{O} \leftrightarrow 2 \mathrm{H}_{3} \mathrm{O}^{+}+1 / 2 \mathrm{O}_{2}+2 \mathrm{e}^{-} \mathrm{pH} \leq 7$

$E_{\left(\mathrm{O}_{2} / \mathrm{H}_{2} \mathrm{O}\right)}^{\circ}=1.23 \mathrm{~V}$ at $\mathrm{pH} 0$

$E_{\left(\mathrm{O}_{2}, \mathrm{H}_{2} \mathrm{O}\right)}^{\circ}=0.81 \mathrm{~V}$ at $\mathrm{pH} 7$

$2 \mathrm{OH}^{-} \leftrightarrow \mathrm{H}_{2} \mathrm{O}+1 / 2 \mathrm{O}_{2}+2 \mathrm{e}^{-} \mathrm{pH}>7$

$E_{\left(\mathrm{O}_{2} / \mathrm{OH}^{-}\right)}^{\circ}=0.39 \mathrm{~V}$ at $\mathrm{pH} 14$

The fluorine electromigration is only possible if it is an ionic species in the liquid phase. For the system studied, the $\mathrm{pH}$ necessary for fluorine desorption must be superior to 11 [11]. Therefore, it 
is necessary to maintain this $\mathrm{pH}$ condition in order to allow the fluoride migration towards the electrodes. This $\mathrm{pH}$ will determine the electrolysis reactions: at the anode, the addition of sodium hydroxide promotes reaction (6) and prevents the formation of $\mathrm{H}_{3} \mathrm{O}^{+}$ions which can migrate towards the cathode and cause an acidification of the soil; at the cathode, the addition of distilled water promotes reaction (4) and impose a basic $\mathrm{pH}$ by the formation of $\mathrm{OH}^{-}$ions. These migrate towards the anode and promote the evolution of the medium to a basic $\mathrm{pH}$.

Water electrolysis reactions follow the quantitative Faraday's law (7). It permits the calculation of the amount of water produced or consumed at the electrodes [23], necessary to verify the mass balances and to determine flows at the electrodes.

$N=\frac{I t}{z F}$

$N$ denotes the number of moles of substances consumed or produced at one electrode, $I$ is the total courant intensity at the interface electrode/ solution, $t$ represents the duration of the electrolysis, $z$ quantifies the number of electrons included in the electrochemical system and $F$ is the Faraday's constant.

Table 2

Composition and characteristics of the soil

\begin{tabular}{ll}
\hline Organic matter & $65 \%$ \\
Total iron & $5.3 \%$ \\
Total calcium & $2.6 \%$ \\
Carbonates & Negligible \\
Total fluorine & $9 \times 10 \mathrm{~kg} \mathrm{~kg}^{-1}$ of soil \\
Fluorine removed by washing a & $0.217 \mathrm{~g} \mathrm{~kg}^{-1}$ of soil \\
C.E.C. & $0.033 \mathrm{eq} \mathrm{kg}^{-1}$ of soil \\
(Cationic exchange capacity) & \\
Particle size & $0-2 \mathrm{~mm}^{-1}$ \\
Specific surface & $9580 \mathrm{~m}^{2} \mathrm{~kg}^{-1}$ \\
Soil dry density & $1670 \mathrm{~kg} \mathrm{~m}^{-3}$ \\
Porosity & 0.32 \\
Water content & $28.55 \%$ \\
Saturation degree & 0.99
\end{tabular}

a AFNOR X31-210 [19].

b AFNOR X31-130 [18].

\subsection{The soil}

The characteristics and the composition of the soil chosen for the study are summarised in Table 2. This soil naturally contained fluorine mainly in the $\mathrm{CaF}_{2}$ form, and fluoride concentrated solid wastes originated by industrial activity [11]. The complete elimination of the fluorine could not be attained because of the possible destruction of the medium.

\subsection{Measurements}

The analysed variables were $\mathrm{pH}$, flow and fluoride concentration at the over-flows, electric potential and current intensity.

Measurements of $\mathrm{pH}$ were performed by introducing the electrode of a $\mathrm{pH}$ meter into the soil. Determination of volume of solution at the overflow was made by weighing, and the fluoride removed at the over-flow was titrated with a specific electrode. Electric potential differences were measured in the soil between the anode and a movable electrode which was displaced throughout the whole cell. For this, a metal rod and a multimeter were used while a second multimeter, in the circuit, allowed the measurements of the current intensity produced during the treatment.

\subsection{Method}

For the experimental study, $0.9 \mathrm{~kg}$ of soil and 0.2571 of $\mathrm{NaOH}(0.01 \mathrm{M})$ were mixed manually and put into the central part of the cell upon which the cover was placed. This was easily removed to allow the measurements. The sodium hydroxide was used to saturate the soil and to induce electrolysis reactions (4) and (6) at the electrodes. In addition, the electric conductivity of the medium was increased by the $\mathrm{Na}^{+}$and $\mathrm{OH}^{-}$ ions added to the soil.

Three electric potentials were applied between the electrodes of the three cells: $25 \mathrm{~V}$ for the $\mathrm{C} 25$ cell, $50 \mathrm{~V}$ for the $\mathrm{C} 50$ cell, $75 \mathrm{~V}$ for the $\mathrm{C} 75$ cell. Once a day, $\mathrm{pH}$ and electric potential measurements are performed in the soil at different positions. During the $\mathrm{pH}$ measurements, the electricity generator was switched off in order not to disturb 
a

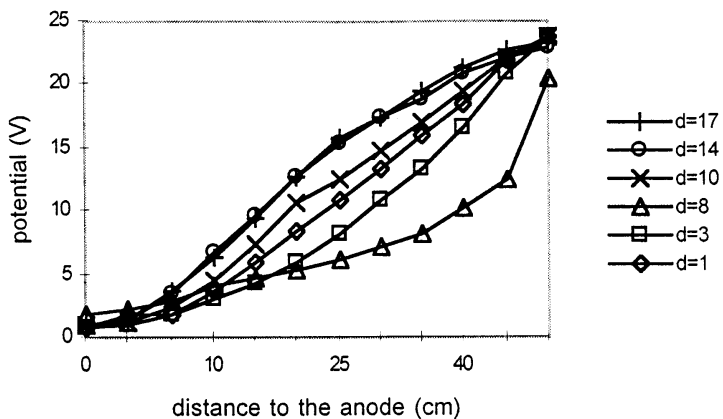

b

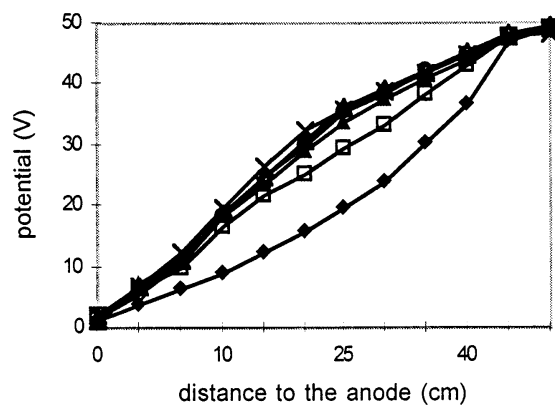

C

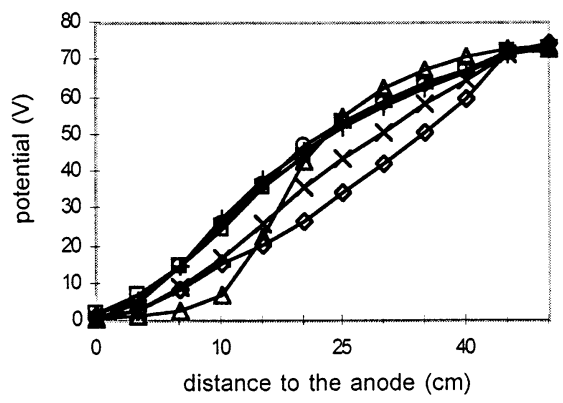

Fig. 2. Evolution of the electric potential distribution, measured in the cells. (a) cell C25; (b) cell C50; (c) cell C75.

the $\mathrm{pH}$ meter. In addition, the solution removed at each over-flow was weighed and about $50 \mathrm{ml}$ of solution was drawn out to determine electroosmotic flow and to perform the fluoride titration. For the measurement of fluoride concentration by a specific electrode, $\mathrm{pH}$ values must be between 4 and 8 in order to avoid fluoride complexation and interference of $\mathrm{OH}^{-}$ions. Mass balances and the fluoride concentrations allow the fluoride migra- tion to be followed during the treatment in the medium.

\section{Results and discussion}

\subsection{Electric potential distribution}

Fig. 2 shows that the electric potential profiles, observed along the electromigration cells, can be assumed linear from the first day of the treatment.

The electric potential gradient, in each cell, is considered constant and equal to $0.5,1$ and $1.5 \mathrm{~V}$ $\mathrm{cm}^{-1}$, when electric potentials of 25,50 and $75 \mathrm{~V}$ are applied, respectively. It is interesting to note that the measured electric potential gradient is the ratio between the tension applied at the electrodes and the total length of the cell.

\subsection{Evolution of soil $\mathrm{pH}$}

Fig. 3 shows, for the three cells, the advance with time of the $\mathrm{pH}$ front from the cathode to the anode whatever the electric potential applied. The soil $\mathrm{pH}$ becomes gradually basic even though initially it was close to 5 in every cell. Finally, the soil has a similar and homogeneous $\mathrm{pH}$ in all the cells, the only difference being the front advance rate which is slower for cell $\mathrm{C} 25$. The greater the electric potential applied between the electrodes is significant, the more rapidly the front advances towards the anode.

After 17 days, the $\mathrm{pH}$ in cells $\mathrm{C} 50$ and $\mathrm{C} 75$ is similar and homogeneous but not in cell $\mathrm{C} 25$ because of the slower front advance. In this case, all the medium is not at the basic $\mathrm{pH}$ necessary for fluorine solubilisation. The electromigration treatment on the $\mathrm{C} 25$ cell was carried on up to 39 days [11], in order to attain the similar homogeneous $\mathrm{pH}$ obtained in cells $\mathrm{C} 50$ and $\mathrm{C} 75$ (Fig. 3(a)). The $\mathrm{pH}$ front advance is a function of the applied electric potential and so, in order to attain the complete pollutant solubilisation in a time defined and to have a chemical pseudo steady state, an threshold electric potential must be applied between the electrodes.

In the electrolyte compartments the $\mathrm{pH}$ is always basic, at the cathode due to electrolysis and 
at the anode due to reagent supply. The stopping of the $\mathrm{NaOH}$ supply between the 4th and the 8th day in cells $\mathrm{C} 25$ and $\mathrm{C} 75$ has produced an acidification of the soil near the anode. In fact, the electrolysis reaction (6) was not promoted and reaction (5) has taken place producing $\mathrm{H}_{3} \mathrm{O}^{+}$ ions.
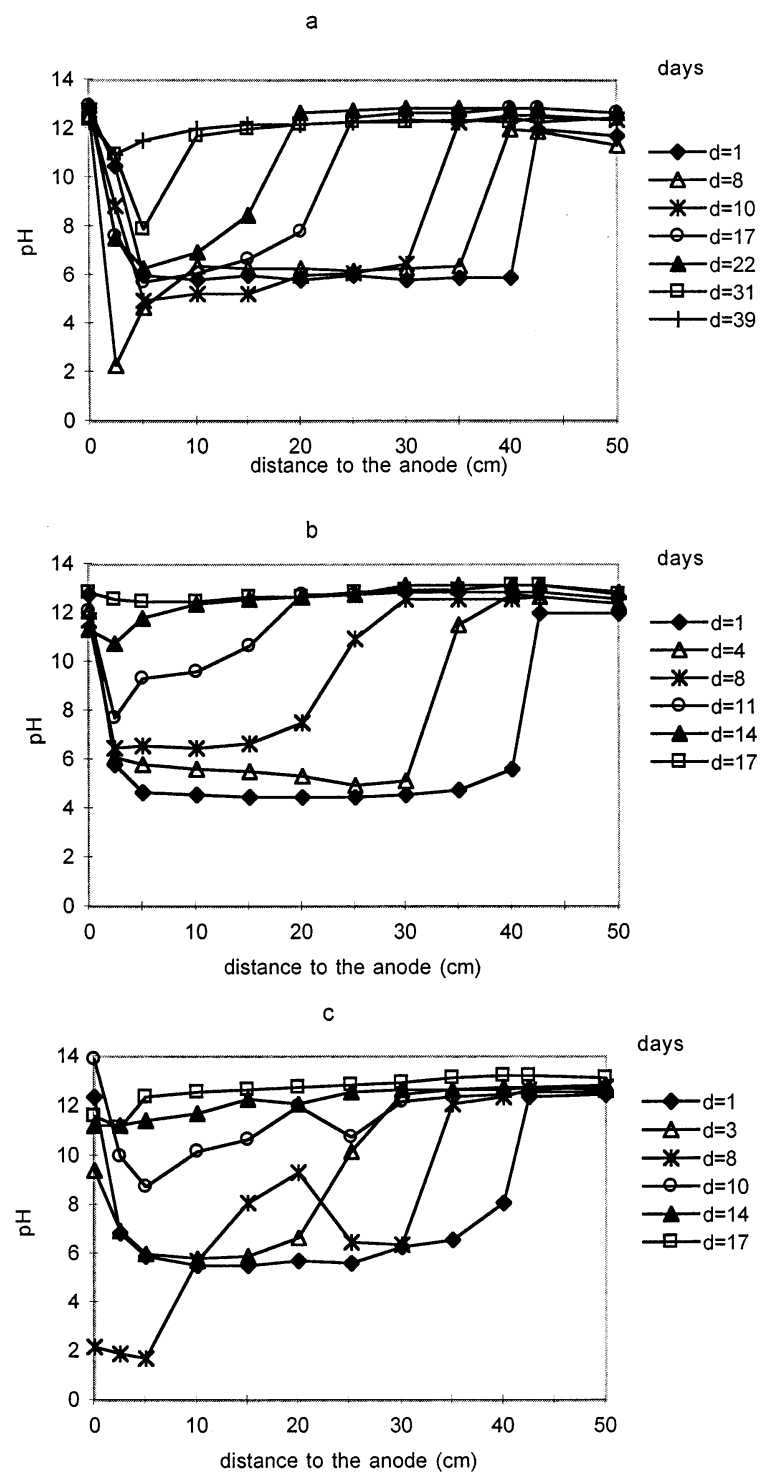

Fig. 3. Evolution of soil pH: (a) cell C25; (b) cell C50; (c) cell C75.

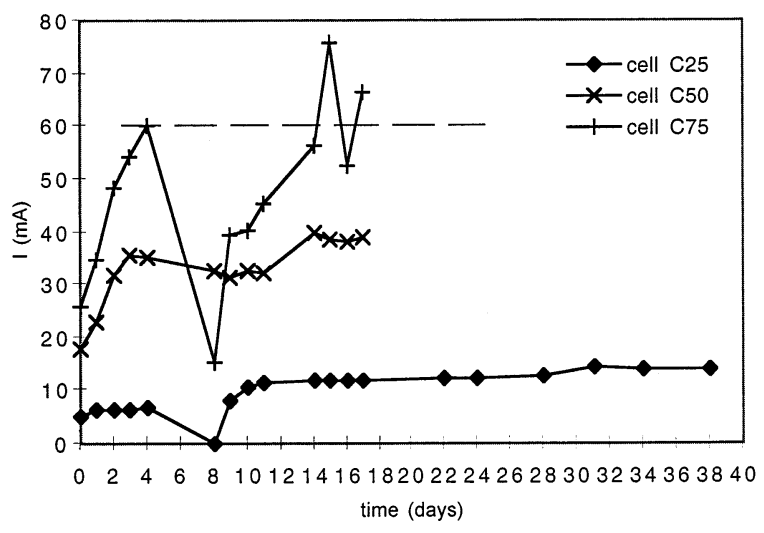

Fig. 4. Evolution with time of the current intensity produced during the treatment measured in the cells.

\subsection{Evolution of the current intensity}

Fig. 4 represents the evolution of the current intensity measured in the circuit during the treatment. From the 4th to the 8th day, cells C25 and C75 were not supplied with reagents producing a sudden decrease of the current intensity which is caused by the ion depletion in the medium. The broken line shown to Fig. 4 does not correspond with experimental data, but could represent the theoretical evolution of the current intensity without the anomaly which occurred between the 4th and the 8th day.

The evolution of the current intensity seems to depend on the chemical conditions of the medium. Figs. 3(b) and 3(c) show that the soil is at a constant $\mathrm{pH}$ after 14 days in cells C50 and C75 and after day 31 in cell C25 as is shown on Fig. 3(a). In these conditions a pseudo steady state is attained and the current intensity remains constant in cells C25 and C50 and it fluctuates around an average value in cell $\mathrm{C} 75$.

The average values of the current intensity at the pseudo steady state are close to: $14.17 \mathrm{~mA}$ for $0.25 \mathrm{~V} \mathrm{~cm}^{-1}$ (average from the 31st to 38th days); $38.88 \mathrm{~mA}$ for $1 \mathrm{~V} \mathrm{~cm}^{-1}$ (average from 14 to 17 th days); $62.71 \mathrm{~mA}$ for $1.5 \mathrm{~V} \mathrm{~cm}^{-1}$ (average from 14 to 17 th days). The response of a substance to an electric field applied is by definition the conductivity $\kappa$ : 
$\kappa=\frac{j}{E}$

with $j$ the electric current density:

$j=\frac{I}{S}$

So, the conductivity can be related to the electric current by:

$\kappa=\frac{I}{S E}$

A substance obeys Ohm's law when its conductivity is independent of the value of the applied electric field [17]. So, for a substance which obeys Ohm's law, the plot of the electric current density as a function of the electric potential must be a straight line, the slope of which is the conductivity.

Using the attained values of current intensity at the pseudo steady state, the electric current density of the soil can be calculated for each electromigration cell. Fig. 5 shows that the soil conductivity remains constant at a value of 3.266 $\mathrm{mS} \mathrm{cm}^{-1}$ for every potential applied. This can demonstrates that, in the pseudo steady state, during an electro-decontamination, a soil obeys Ohm's law.

\section{Conductivity}

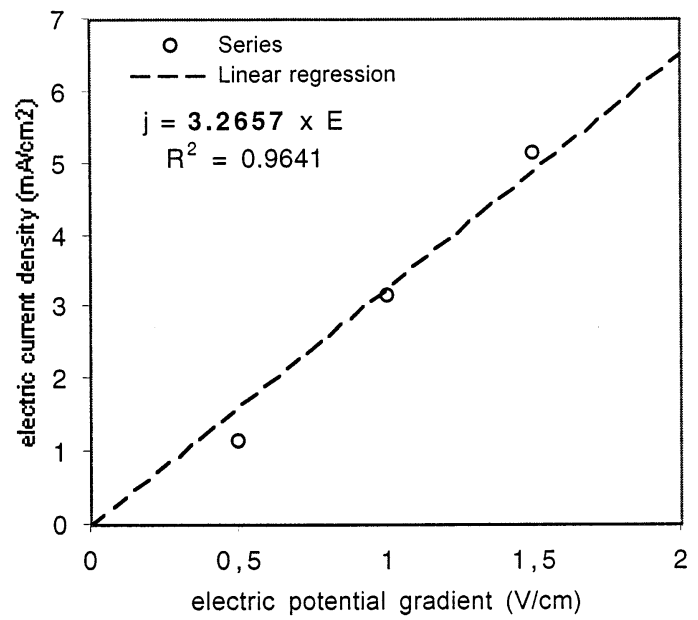

Fig. 5. Evolution of the electric current density with the electric potential gradient.
Under these conditions, the existence of a soil conductivity independent of the electric field allows an estimation of the cost of the process, which is a function of the electric current produced during the treatment, and that can be easily estimated from the applied electric field.

However, cell C25 did not reach the pseudo steady state at the same time as the other cells and 23 days more were needed. An threshold electric potential, applied to the electromigration cell, seems to be necessary to overcome the viscosity and the interionic forces.

\subsection{Fluorine removed from the soil}

Fluoride recovered at the anode (Fig. 6(a)) involves electromigration as the transport mechanism while at the cathode (Fig. 6(b)). Fluorine is removed by electroosmosis as fluoride or other soluble species such as fluorine complexes. The sense of electroosmotic flow depends on the zeta potential of the medium. At a basic $\mathrm{pH}$ the surface charges of the particles are negative and the zeta potential is negative too so, under these conditions electroosmotic flow is towards the cathode.

The broken line shown in Fig. 6(c), which represents the cumulative mass of fluorine recovered from the soil, indicates the amount of fluorine removed by washing which is listed in Table 2. The electromigration, after 17 days of treatment, allows the recovery of 1.8 times more fluorine than by washing (normalised process [19]).

The amount of fluorine recovered at the anode during the first days of the treatment is not significant, but this increases quickly from the 12th day for cells C50 and C75. It is also from the 12th day that all soil of cells $\mathrm{C} 50$ and $\mathrm{C} 75$ reaches the $\mathrm{pH}$ of maximum solubilisation of the fluorine as it was shown in Figs. 3(b) and 3(c). Recovery of fluorine in cell C25 is not significant for the same duration of treatment but, as was shown in Fig. 3(a), the soil has not attained a $\mathrm{pH}$ equal to 11 the 17 th day. The fluoride in this cell remains, for the most part, solid adsorbed on the soil particles. In addition if the soil is not supplied with chemical reagents, $\mathrm{pH}$ conditions are not controlled so, they will depend on the electrolysis reactions. 

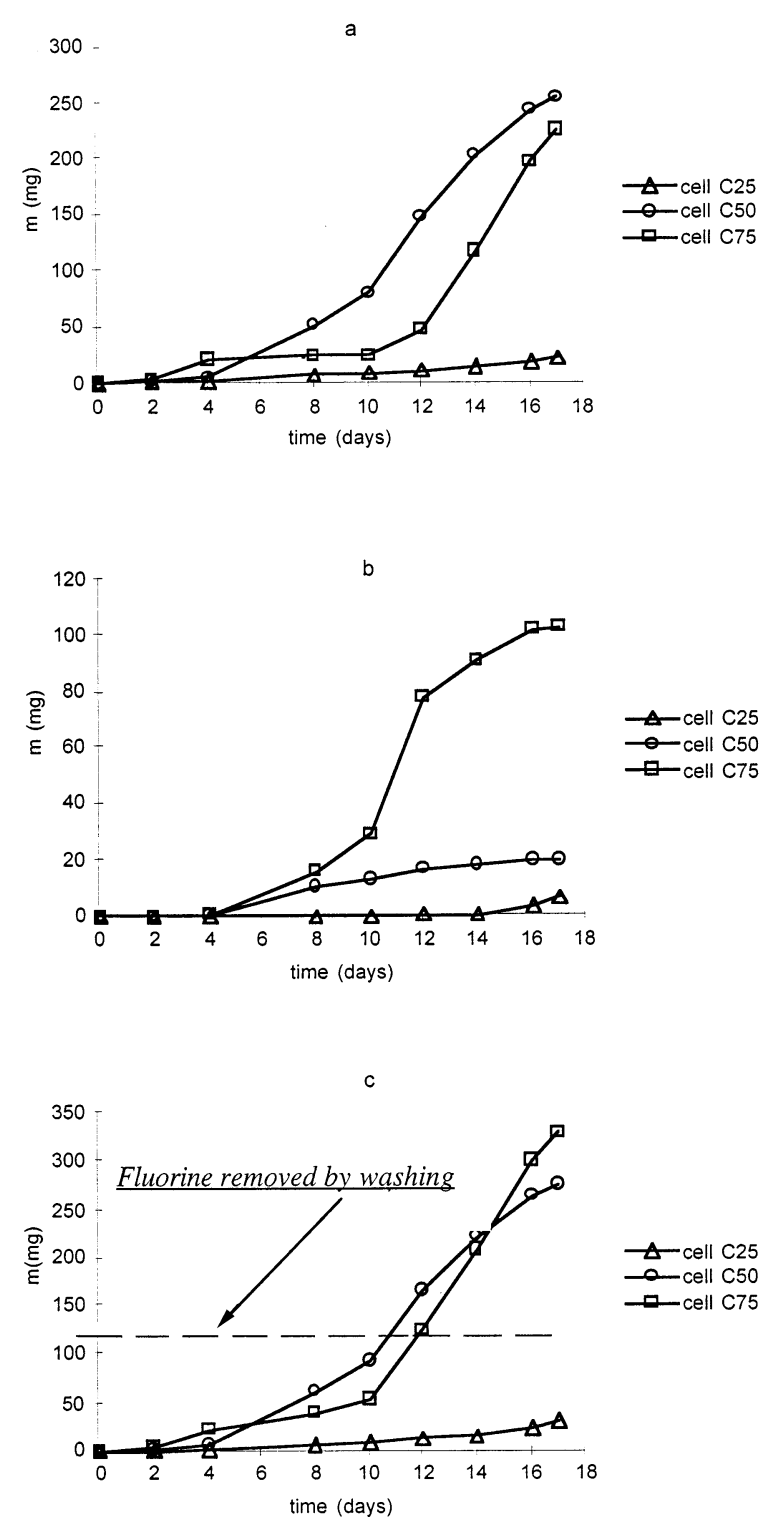

Fig. 6. Cumulative mass of fluorine removed in the effluents: (a) fluorine at the anode; (b) fluorine at the cathode; (c) total fluorine.

Acid or basic $\mathrm{pH}$ fronts could appear in the soil and the pollutant could remain accumulated by adsorption or precipitation, or its sense of migration can be reversed by a change of its chemical form [16].

Results obtain for cell C25 show that too small an applied electric potential gradient does not promote the electrokinetic phenomena.

\section{Conclusion}

The experimental study realised has shown that pollutant and soil chemical interactions must be well controlled to obtain an efficient electro-decontamination. In fact, species migrate only if they are in solution so, the $\mathrm{pH}$ solubilisation of these species needs to be controlled by the addition of reagents at the electrodes. In this way, we note that it is only when all of the medium has favourable $\mathrm{pH}$ conditions that the amount of fluorine recovery becomes significant.

In addition, an threshold electric field is necessary to promote the electrokinetic remediation. But, too high an electric potential increases the cost of the electro-decontamination because of the large current intensity produced in the medium. Soil conductivity is the ratio between electric current density and the electric potential gradient, which is constant for a soil at constant chemical conditions. From this the cost of the electro-decontamination technique is easily estimated since, at the pseudo steady state, the current intensity remains at a stable value.

However, the use of a natural soil make the knowledge of pollutant-soil interactions and the analysis of transport phenomena, difficult. Under these conditions the use of a well known soil model would allow a precise study of transport mechanisms, necessary to model the process. Experiments have shown that the proposed electromigration cells can be used to study transport phenomena but some problems, such as the difficulty in controlling the porosity or the significant evaporation, must be avoided. Other types of electromigration cells are reported in the literature $[3,20,22]$. These cells seem better because the control of the physical properties of the soil (porosity and water content) is possible.

List of symbols

\begin{tabular}{ll}
\hline$E$ & electric potential gradient $\left(\mathrm{V} \mathrm{m}^{-1}\right)$ \\
$E^{\circ}$ & electrode normal potential $(\mathrm{V})$ \\
$F$ & Faraday s constant, $\mathrm{F}=96484 \mathrm{C} \mathrm{mol}^{-1}$ \\
$H$ & hydraulic head $(\mathrm{Pa})$ \\
$H / L$ & hydraulic head gradient $\left(\mathrm{Pa} \mathrm{m}^{-1}\right)$
\end{tabular}


I total current intensity at the interface electrode/solution (A)

$j \quad$ electric current density $\left(\mathrm{A} \mathrm{m}^{-2}\right)$

$\kappa \quad$ conductivity $\left(\mathrm{S} \mathrm{m}^{-1}\right)$

$k_{\mathrm{e}} \quad$ coefficient of electroosmotic permeability $\left(\mathrm{m}^{2} \mathrm{~s}^{-1} \mathrm{~V}^{-1}\right)$

$k_{\mathrm{h}} \quad$ hydraulic permeability $\left(\mathrm{m}^{2} \mathrm{~Pa}^{-1} \mathrm{~s}^{-1}\right)$

$L \quad$ length of the porous medium (m)

$m$ cumulative mass $(\mathrm{mg})$

$n \quad$ porosity

$N \quad$ number of moles of substance consumed or produced at one electrode (mol)

$q_{\mathrm{e}} \quad$ electroosmotic flow $\left(\mathrm{m}^{3} \mathrm{~s}^{-1}\right)$

$q_{\mathrm{h}} \quad$ water flow $\left(\mathrm{m}^{3} \mathrm{~s}^{-1}\right)$

$S \quad$ section of porous medium $\left(\mathrm{m}^{2}\right)$

$t \quad$ duration of the electrolysis (s)

$V \quad$ electric potential (V)

$z$ number of electrons included in the electrochemical system

\section{References}

[1] Y.B. Acar, J. Hamed, Electrokinetic soil processing in remediation/treatment; synthesis of available data. Energy and Environmental Issues, Bull. Transportation Research Record 1312 (1992) 153-161.

[2] Y.B. Acar, H. Li, R.J. Gale, Phenol Removal from Kaolinite by Electrokinetics, ASCE J. Geotech. Eng. 118 (1992) 1837.

[3] Y.B. Acar, R.J. Gale, A.N. Alshawabkeh, R.E. Marks, S. Puppala, M. Bricka, R. Parker, Electrokinetic Remediation: Basics and Technology Status, J. Hazard. Mater. 40 (1995) 117-137.

[4] Y.B. Acar, A.N. Alshawabkeh, Electrokinetic Remediation. I: Pilot-Scale Tests with Lead-Spiked Kaolinite, J. Geotech. Eng. 112 (3) (1996) 173-185.

[5] E.V. Ballou, Electroosmotic Flow in Homonionic Kaolinite, J. Colloid Sci. 10 (5) (1955) 450-460.

[6] S. Blanco, Mécanisme de Séparation des protéines par électrophorèse. Modélisation et Analyse de Sensibilité. PhD Thesis, Université Paul Sabatier, Toulouse, France, (1996).
[7] M. Bonnemay, J. Royon, Electroosmose. Techniques de l'Ingénieur. D912 1-12 (1974).

[8] C.J. Bruell, B.A. Segall, M.T. Walsh, Electroosmotic Removal of Gasoline Hydrocarbons and TCE from Clay, J. Environ. Eng. 118 (1) (1992) 68-83.

[9] H. Cambefort, C. Caron, Electroosmose et Consolidation Electrochimique des Argiles Geotechnique. (1961).

[10] L. Casagrande, Electroosmosis in soils, Geotechnique. 1 (3) (1949) 159-177.

[11] N. Costarramone, Mise en Oeuvre au Laboratoire et au Stade Pilote de la Decontamination Electrocinetique d'un Sol, dans le cas d'une Pollution Fluorée. PhD Thesis, Université de Pau et des Pays de l'Adour, Pau, France, 1996.

[12] E. Guyon, J.-P. Hulin, L. Petit, Hydrodynamique Physique. InterEditions/Editions du CNRS (1991).

[13] R.A. Jacobs, R.F. Probstein, Two-Dimensional Modeling of Electroremediation, AIChE J. 42 (1996) 6.

[14] R. Lageman, Electroreclamation: Applications in the Netherlands, Environ. Sci. Technol. 27 (13) (1989) $2648-$ 2650.

[15] P. Lecomte, Les Sites Pollues: Traitement des sols et des eaux souterraines. Technique et Documentation, Lavoisier, Paris.

[16] S. Lesoin, Migration cationique et anionique des metaux toxiques (plomb, chrome, zinc) dans les sols sous l'effet d'un champ electrique. PhD Thesis, Ecole Nationale des Ponts et Chaussees, France, 1997.

[17] I.N Levine, Physical chemistry, McGraw Hill, Mexique, 1978.

[18] NORME AFNORX31-130 may (1993)

[19] NORME AFNORX31-210 september (1988)

[20] Pamucku, S., Khan, L.J. and Fang, H.Y. Zinc, Teoxification of Soils. Bull. Transportation Research Record, $N^{\circ}$ 1288, Soils Geology and Fundations, Geotechnical Engineering. 41 (1990).

[21] S. Pamucku, J.K. Wittle, Electrokinetic Removal of Selected Heavy Metals from Soil, Environ. Prog. 11 (1992) 3.

[22] A.P. Shapiro, P.C. Renaud, R.F. Probstein, Preliminary Studies on the Removal of Chemical Species from Saturated Porous Media by Eleckoosmosis, PCH Physico Chemical Hydrodynamics. 11 (5-6) (1989) 785-802.

[23] B. Tremillon, Electrochimie Analytique et Reactions en Solution, TOME 2, Reactions et Methodes Electrochimiques, Masson, 1993. 